\title{
EFEKTIVITAS VAKSIN TY21A ORAL DIBANDINGKAN DENGAN VAKSIN PARENTERAL DALAM PENCEGAHAN TRANSMISI DEMAM TIFOID BAGI WISATAWAN
}

\author{
${ }^{1}$ Manatar, A.F., dan ${ }^{1}$ Hadiwijaya, R.R. \\ ${ }^{1}$ Fakultas Kedokteran Universitas Sam Ratulangi Manado \\ (ambhitoex_girl01@yahoo.com)
}

\section{ABSTRAK}

Perjalanan internasional, termasuk perjalanan ke negara-negara miskin dan berkembang telah meningkat. Lebih dari 900 juta orang melakukan perjalanan internasional setiap tahunnya. Risiko terjadinya penularan saat berwisata sangat bervariasi, tergantung dari tingkat kedekatan hubungan, lamanya kontak, dan sifat kontak tersebut. Demam tifoid merupakan salah satu masalah kesehatan bagi wisatawan di negara-negara berkembang, karena bisa meningkatkan angka morbiditas dan mortalitas. Karena itulah dibutuhkan suatu tindakan pencegahan dalam rangka menurunkan insiden demam tifoid khususnya untuk wisatawan. Pencegahan untuk demam tifoid yang tersedia saat ini yaitu vaksinasi. Terdapat dua jenis vaksin yang banyak digunakan, yaitu vaksin parenteral dan vaksin oral Ty21a. Kedua vaksin ini mempunyai keuntungan dan kerugian masing-masing. Karena itulah perlu diketahui vaksin mana yang lebih diunggulkan dan efektivitas penggunaanya terhadap upaya pencegahan transmisi demam tifoid, khususnya bagi wisatawan yang berisiko untuk terpapar.

Kata Kunci: Demam tifoid, wisatawan, pencegahan transmisi, vaksin Ty21a, respon imun, efektivitas vaksin Ty21a

\section{ABSTRACT}

International travel, including travelling to poor and developing country has increased. More than 900 million people travel internationally each year. The risk of infection while travelling varies widely, depending on the closeness of relationship, length of exposure, and nature of the contact. Typhoid fever is one of many health problems for travelers in developing country, because it can increase the morbidity and mortality rate. That's why it takes a precautionary measure to reduce the incidence of typhoid fever especially for travelers. The current preventive intervention for typhoid fever is vaccination. There are two kinds of vaccines that are widely used, such as parenteral vaccine and oral Ty21a vaccine. These vaccines have it's own up and downside. That's why we have to find out which vaccine is better to prevent the transmission of typhoid fever, especially for high risk traveler..

\section{PENDAHULUAN}

Dunia pada milenium ke tiga ini serasa semakin kecil akibat mudahnya transportasi dan komunikasi. Pada tahun 2000 tercatat 692 juta orang bepergian lintas negara, diperkirakan pada tahun 2010 akan mencapai 1,047 milyar, dan pada tahun 2020 mencapai sekitar 1,602 milyar. Selain peningkatan jumlah yang hampir $3 x$ lipat dalam 20 tahun ke depan, tampaknya akan terjadi perubahan karakteristik dengan peningkatan yang tajam di Asia dan Eropa. Hal tersebut akan berdampak pada kesehatan karena pajanan terhadap penyakit infeksi akan semakin tinggi dan akan lebih mudah untuk membawa pathogen ke berbagai negara. ${ }^{1}$

Studi pada wisatawan dari negara maju ke negara berkembang dan Eropa Timur menunjukkan bahwa lebih dari sepertiganya mengalami sakit saat bepergian. Pada setiap 2 minggu perjalanan mereka akan kehilangan 3 hari karena sakit. Dua puluh persen dari mereka akan tetap sakit sepulang ke Negara asalnya dan $10 \%$ akhirnya pergi ke dokter untuk berobat. $^{2}$

Peningkatan jumlah wisatawan antar negara akan diikuti peningkatan risiko terkena penyakit infeksi. $^{3}$ Penyakit enterik merupakan salah satu penyebab masalah utama pada wisatawan. Ketika berada jauh dari rumah, para wisatawan bisa menghindari banyak paparan yang dapat meningkatkan risiko penyakit infeksi, tapi tidak dapat menghindari seluruh paparan terhadap makanan dan minuman, termasuk media yang membawa organisme penyebab seperti demam tifoid dan kolera. ${ }^{4}$

Hanya kuman patogen yang sangat infeksius termasuk Salmonella typhi penyebab demam tifoid, yang dapat ditularkan saat kontak di tempat umum dengan sanitasi yang kurang memadai. Oleh sebab itu, bila akan berkunjung di daerah tersebut perlu dilakukan upaya preventif. Dan inilah yang mendorong 
para wisatawan yang berkunjung ke daerah berisiko terserang penyakit demam tifoid untuk melakukan pencegahan dengan cara vaksinasi. Vaksinasi sebelum bepergian ke daerah endemik juga sudah direkomendasikan oleh International Health Regulation dalam upaya pencegahan demam tifoid. ${ }^{4}$

Oleh Germanier dan Fuhrer, ${ }^{5}$ ditemukan suatu vaksin oral yang cukup poten, yang berasal dari strain S. typhi yang dilemahkan, Ty 21a. Vaksin oral ini, pada studi pendahuluan terhadap sukarelawan di Amerika Utara, memberi perlindungan yang sangat bermakna tanpa adanya gejala sampingan seperti yang terdapat pada vaksin parenteral (kuman yang dimatikan). ${ }^{6}$ Vaksin-parenteral Salmonella typhi yang dimatikan, yang selama ini dipakai untuk pencegahan penyakit demam tifoid, selain mempunyai daya proteksi yang sedang $(40-80 \%)$, juga mempunyai gejala samping yang sangat mengganggu. Dengan ditemukannya vaksin-oral yang diperkirakan cukup poten yang terdiri dari strain Ty21a S. typhi yang dilemahkan oleh Germanier, timbul suatu harapan yang menggembirakan untuk mencegah penyakit tifoid di mana dalam uji coba pertamaterhadap masyarakat di Mesir mempunyai efikasi sebesar $96 \%$.

\section{Perkembangan Vaksin Demam Tifoid}

Awalnya, salah satu vaksin yang digunakan untuk demam tifoid ialah vaksin parenteral, yang merupakan seluruh sel Salmonella typhi yang dimatikan dengan aseton atau yang dipanasi dengan phenol sebagai bahan pengawet. Vaksin parenteral ini memberi daya perlindungan yang bervariasi di berbagai negara. Dahulu, uji coba lapangan di dua tempat, yaitu Polandia dan Jugoslavia ${ }^{7,8}$, memberi perlindungan sebesar $51-86 \%$, dan di pulau Tonga ${ }^{9}$ memberi perlindungan yang kira-kira sama besarnya. Vaksin yang diberikan secara parenteral ini menimbulkan gejala samping berupa demam dan badan lesu secara sistemik, rasa sakit, indurasi dan kemerahan di tempat suntikan (lokal).

Walaupun efektivitasnya cukup besar, akan tetapi timbulnya gejala samping yang sangat tidak menyenangkan, menyebabkan pemakaian vaksin ini kurang popular, bahkan pemakaiannya di Indonesia secara nasional tidak dianjurkan. Oleh sebab itu, Germanier dan Fuhrer ${ }^{5}$, menemukan suatu vaksin oral yang cukup poten, yang berasal dari strain Salmonella typhi yang dilemahkan, Ty21a. Vaksin oral ini, pada studi pendahuluan terhadap sukarelawan di Amerika Utara, memberi perlindungan yang sangat bermakna tanpa adanya gejala sampingan seperti yang terdapat pada vaksin parenteral. ${ }^{6}$

Selain itu, uji coba di lapangan di Alexandria, Mesir oleh Wandan $\mathrm{dkk}^{10}$, vaksin oral yang telah ditemukan pada waktu itu memberi daya pērlindungan sebesar $95 \%$ untuk masa paling sedikit 3 tahun. Menyusul uji coba di Mesir, oleh Levine dkk ${ }^{11}$, telah pula dilakukan uji coba di lapangan di Santiago, Chili. Hasilnya sungguh di luar dugaan, karena memberi daya perlindungan yang berbeda dengan uji coba di Mesir. Uji coba di Chili memberi perlindungan hanya sebesar 54-62\%.

Vaksin parenteral demam tifoid seperti vaksin Typa atau Chotypa, sebenarnya sudah memberi daya perlindungan yang cukup lumayan ${ }^{7,8,9}$, akan tetapi vaksin ini memberi gejala sampingan yang sangat mengganggu. Selain itu, pemberian vaksinnya memerlukan persiapan dan peralatan suntik serta harus diberikan oleh tenaga medis atau paramedis.

Vaksin oral dari sel S. typhi yang dimatikan, telah pula coba dipergunakan. Akan tetapi walaupun vaksin ini tidak memberi gejala samping, vaksin ini tidak dapat dipergunakan karena tidak memberi daya perlindungan yang memadai. ${ }^{12}$ Oleh karena itu vaksin oral kuman hidup yang dilemahkan dari strain Ty21a penemuan Germanier ${ }^{5}$, merupakan jalan keluar sebagai usaha untuk memberantas penyakit demam tifoid melalui imunisasi.

Mutasi galaktosa epimerase dari Salmonella typhi telah diisolasi oleh Germanier. Hasil yang diperoleh menunjukkan bahwa mutan ini memiliki potensi untuk digunakan sebagai vaksin hidup yang dilemahkan dan digunakan secara oral. Mutan ty21a, mengambil galaktosa dari sumber eksogen. Kemudian, setelah terjadi akumulasi yang cukup dari galaktosa-1fosfat serta galaktosa uridin difosfat menyebabkan sel bakteri menjadi lisis sehingga mengakibatkan avirulensi strain. Galaktosa dimasukkan kedalam dinding sel ty21a untuk memungkinkan sintesis lipopolisakarida halus yang diperlukan untuk imunogenitas yang tepat. ${ }^{5}$ S. typhi strain Ty21a yang dilemahkan, telah terbukti aman dan berkhasiat sebagai vaksin oral dalam studi klinis dan uji coba lapangan terkontrol, yang secara ekstensif dicirikan oleh data genetika, biokimia dan biologis. Karakteristik Ty21a relevan dengan avirulensi dan potensinya.

Avirulensi disebabkan karena defek uridin difosfogalaktosa 4-epimerase pada strain Salmonella sehingga bakteri tidak lagi memiliki antigen Vi tetapi masih mengandung polisakarida dinding sel yang imunogenik. Vaksinasi primer terdiri dari 1 kapsul enterik berlapis atau lyophilised sachet. ${ }^{13}$

Mekanisme vaksin ini menimbulkan antibody serum dan mukosa untuk Salmonella typhi $\mathrm{O}, \mathrm{H}$, dan antigen lainnya melalui inisiasi respon imun Cell Mediated Immune (sel T sitotoksik). Efikasi vaksin ini sekitar $50-78 \%$ dan durasi perlindungan mencapai 3 sampai 4 tahun. ${ }^{14}$ 


\section{Penyebaran Demam Tifoid}

Demam tifoid masih merupakan penyakit endemik di Asia Tenggara termasuk Indonesia. Insiden infeksi tertinggi terjadi pada usia 1-4 tahun. Angka kematian lebih tinggi pada bayi, orang dewasa dan pada orang dengan sistem kekebalan tubuh yang menurun (HIV, keganasan). ${ }^{15,16}$ Demam tifoid hingga saat ini masih merupakan masalah kesehatan masyarakat di negara yang sedang berkembang termasuk di Indonesia. ${ }^{17,18}$

Demam Tifoid adalah penyakit infeksi akut yang disebabkan oleh bakteri Salmonella enterica serotype typhi (S. Typhi). ${ }^{19}$ S. typhi dikarakterisasi oleh antigen lipopolisakarida (antigen 09 dan 12), antigen flagela ( $\mathrm{H}$ tipe $\mathrm{d}$ ) dan capsular polysaccharide (Vi, untuk virulensi), serta memiliki gejala demam dan abdominal. ${ }^{4}$ Penyebarannya terjadi secara oral fekal ${ }^{15,19,20}$, oleh karena itu pada daerah dengan sanitasi rendah dan air bersih terbatas, penyakit ini mudah ditemui.

Penyakit ini menyerang sekitar 22 juta orang per tahun dengan angka kematian mencapai 200.000 jiwa per tahun. ${ }^{20}$ Demam tifoid juga merupakan penyebab penting angka kesakitan pada anak. ${ }^{4}$ Menurut WHO, pada tahun 2003 terdapat sekitar 900.000 kasus di Indonesia, dimana sekitar 20.000 penderitanya meninggal dunia.

\section{Proteksi Vaksin Terhadap Penyebaran Transmisi Demam Tifoid}

Pada suatu meta-analisis dari berbagai penelitian mengenai efektivitas berbagai jenis vaksin untuk demam tifoid didapatkan bahwa vaksin Ty21a yang diberikan sebanyak tiga dosis memiliki efektivitas sebesar 35\% pada tahun pertama (8-54\%), 58\% pada tahun kedua (40-71\%) dan $46 \%$ pada tahun ketiga (672\%). Sehingga dengan demikian dapat disimpulkan bahwa tiga dosis vaksin Ty21a memiliki efektivitas sampai tiga tahun. Selain itu vaksin Ty21a berbentuk cair juga didapatkan memiliki efektivitas yang lebih baik bila dibandingkan dengan bentuk sediaan kapsul enterik namun tidak didapatkan perbedaan yang bermakna antara efektivitas kedua bentuk sediaan tersebut. $^{21}$

Pada meta-analisis tersebut juga didapatkan bahwa vaksin tifoid yang lainnya, mengandung polisakarida Vi memiliki efektivitas sebesar $68 \%$ pada tahun pertama $(50-80 \%)$ dan $60 \%$ pada tahun kedua (31-76\%). Di lain pihak berbagai penelitian menunjukkan bahwa vaksin polisakarida Vi tidak memberikan perlindungan yang nyata atau bermakna mulai dari tahun keempat setelah pemberian vaksin. ${ }^{21}$ $\mathrm{Hal}$ ini berkaitan dengan proses imunologis yang terjadi setelah pemberian vaksin. Terjadinya efikasi jangka panjang oleh vaksin membutuhkan adanya memori imunologis jenis Th1 dan antibodi antiSalmonella. Dalam hal ini interaksi antara sel T dan sel B sangatlah penting. Untuk mendapatkan perlindungan tersebut tampaknya pemberian vaksin secara oral lebih efektif dibandingkan dengan pemberian secara parenteral (suntikan). ${ }^{21}$

Tindakan preventif berupa vaksinasi tifoid ini tergantung pada faktor risiko yang berkaitan, yaitu individual atau populasi dengan situasi epidemiologisnya: ${ }^{16}$

- Populasi: anak usia sekolah di daerah endemik, personil militer, petugas rumah sakit, laboratorium kesehatan, industri makanan/minuman.

- Individual: pengunjung/wisatawan ke daerah endemik, orang yang kontak erat dengan pengidap tifoid (karier).

Berdasarkan hasil penelitian dahulu di Plaju, Sumatera $^{22}$ jelas diketahui bahwa vaksin Ty21a memiliki efektivitas yang tinggi dan juga proteksi jangka panjang, serta memiliki efek samping yang lebih kecil dibandingkan dengan vaksin tifoid lainnya. Oleh karena itu vaksin strain ini cocok untuk menjadi vaksin pilihan pertama bagi wisatawan.

\section{Metode Penelitian}

\section{Rancangan Penelitian}

Penelitian ini merupakan penelitian deskriptif dengan merangkum data diperoleh dari berbagai kepustakaan berupa textbook, jurnal maupun artikel kesehatan. Dan kemudian dianalisa guna mendapat kesimpulan akhir.

\section{Pengolahan Data}

Data karya ilmiah ini dikumpulkan dari berbagai textbook, jurnal maupun artikel kesehatan. Kemudian seluruh data terkumpul diolah, dirangkum, dan disajikan dalam bentuk skema, tabel, maupun gambar.

\section{Alur Penelitian}

Pemilihan latar belakang dilakukan sebagai langkah awal dilakukannya penelitian. Setelah latar belakang ditentukan, dicari data-data yang berkaitan dengan pemilihan latar belakang masalah yang diangkat melalui berbagai sumber. Sumber primer diperoleh dari jurnal yang terkait langsung dengan penelitian. Data sekunder diperoleh dari textbook, artikel ataupun referensi lain yang sesuai. Setelah seluruh data terkumpul, kemudian dirangkum, dilakukan pengkajian berupa analisis dan sintesis untuk menjawab masalah yang diajukan dalam latar belakang penelitian. Sebagai tahap akhir penelitian, 
dibuat simpulan yang mencakup seluruh hasil dan pembahasan penelitian.

\section{HASIL}

Berdasarkan hasil percobaan vaksin pada masyarakat Plaju Maka dilakukan uji-coba vaksin Ty21a oral ini secara acak tersamar ganda dengan kontrol plasebo pada karyawan Pertamina Plaju, Palembang dan keluarganya yang insidensinya 12-14 kali lebih besar dari Mesir dan 3-5 kali lebih besar dari Chili. $^{23}$

Vaksin yang dipakai dikemas dalam 2 bentuk, yakni kapsul berlapis enterik dan kemasan bubuk. Pada saat akan diminum kemasan bubuk diencerkan dulu dengan buffer citrat, guna menetralisir asam lambung. Placebo yang dipakai terdiri dari Lactobacillus acidophilus yang dimatikan mempunyai bentuk dan rasa seperti vaksin. Vaksin dan placebo diberikan 3 dosis dengan selang 1 minggu antara dosis. Yang menjadi sasaran vaksinasi ialah Karyawan Pertamina dan keluarganya yang berumur 3-44 tahun. Mereka dibagi dalam 4 kelompok sama besar secara acak, masing-masing kelompok akan mendapat vaksin kapsul, vaksin bubuk, plasebo kapsul dan plasebo bubuk secara seimbang. Masing-masing kelompok disebut dengan kode A, D, C dan E. Setiap orang, dewasa atau anak-anak akan mendapat 3 dosis vaksin dengan selang waktu satu minggu. ${ }^{22}$

Tabel 1. Jumlah Penduduk Plaju yang Divaksinasi dengan Ty21a Oral

\begin{tabular}{|c|c|c|c|c|c|c|c|c|c|c|}
\hline \multirow{3}{*}{$\begin{array}{c}\text { Dosis } \\
\text { Vaksin }\end{array}$} & & & \multicolumn{4}{|c|}{ Jenis / Golongan Vaksin } & & & \multirow{2}{*}{\multicolumn{2}{|c|}{ Jumlah }} \\
\hline & \multicolumn{2}{|c|}{ A } & \multicolumn{2}{|c|}{$D$} & \multicolumn{2}{|c|}{ c } & \multicolumn{2}{|c|}{ E } & & \\
\hline & Jumlah & $\%$ & Jumlah & $\%$ & Jumlah & $\%$ & Jumlah & $\%$ & lumlah & $\%$ \\
\hline 1 & 115 & 2,08 & 124 & 2,25 & 128 & 2,32 & 164 & 3,00 & 531 & 2,40 \\
\hline 2 & 202 & 3,66 & 253 & 4,60 & 234 & 2,25 & 238 & 4,35 & 927 & 4,20 \\
\hline 3 & 5.209 & 94,26 & 5.122 & 93,15 & 5.146 & 93,43 & 5.066 & 92,65 & 20.543 & 93,40 \\
\hline Jumlah & 5.526 & 100,0 & 5.499 & 100,0 & 5.508 & 100,0 & 5.468 & 100,0 & 22.001 & 100,0 \\
\hline
\end{tabular}

Dari data tabel diatas diketahui sebanyak 22.001 orang Karyawan Pertamina Plaju dan Keluarganya yang divaksinasi, di mana 20.543 orang berhasil mendapat 3 dosis, 927 orang dengan 2 dosis dan 531 orang dengan 1 dosis saja.

Tabel 2. Penduduk Plaju yang mendapat Vaksin Oral Ty21a dalam Bentuk Kapsul dan Bubuk.

\begin{tabular}{|c|r|r|r|r|r|r|}
\hline \multirow{2}{*}{$\begin{array}{c}\text { Dosis } \\
\text { Vaksin }\end{array}$} & \multicolumn{2}{|c|}{ Kapsul enteric berlapis } & \multicolumn{4}{c|}{ Bubuk } \\
\cline { 2 - 7 } & \multicolumn{1}{c|}{$\mathrm{A}$} & \multicolumn{1}{c|}{$\mathrm{D}$} & Jumlah & \multicolumn{1}{c|}{ C } & E & Jumlah \\
\hline 1 & 115 & 124 & 239 & 128 & 164 & 292 \\
2 & 202 & 253 & 455 & 234 & 238 & 472 \\
3 & 5.209 & 5.122 & 10.331 & 5.146 & 5.066 & 10.212 \\
\hline & 5.526 & 5.499 & 11.025 & 5.508 & 5.468 & 10.976 \\
\hline
\end{tabular}

Efektivitas vaksin dilihat dengan membandingkan jumlah peserta yang menderita demam tifoid dari kelompok yang mendapat placebo dan kelompok yang mendapat vaksin dengan konfirmasi biakan darah selama 2,5 tahun pelacakan, dimulai dari 3 minggu setelah dosis terakhir diberikan. Ternyata dari 20.543 peserta yang divaksinasi ada 6.347 yang menderita demam dan yang dikultur darahnya secara bakteriologis, dan 307 diantaranya positf S. typhi. Pada analisis diperoleh hasil bahwa insidensi demam tifoid pada kelompok placebo adalah 810 kasus per 100.000 penduduk pertahun. Efikasi vaksin kapsul $(42,2 \%)$ ternyata lebih rendah dari vaksin kemasan bubuk $(53,2 \%)$, walaupun perbedan ini tidak bermakna secara statistik. Vaksin memberikan efikasi yang tak jauh berbeda antara laki-laki dan perempuan. ${ }^{24}$

Tabel 3. Pemeriksaan Darah yang Positif terhadap Salmonella dari Kasus-kasus demam yang berobat ke R.S. Pertamina Plaju.

\begin{tabular}{|c|r|r|r|r|}
\hline \multirow{2}{*}{ Bulan } & Iumlah & \multicolumn{3}{|c|}{ Positif untuk } \\
\cline { 2 - 5 } & $\begin{array}{c}\text { Dipe- } \\
\text { riksa }\end{array}$ & S. typhi (\%) & S. paratyphi A (\%) & $\begin{array}{l}\text { Salmonella } \\
\text { Group C }\end{array}$ \\
\hline 22-31 Sept. 1986 & 71 & $9(12,6)$ & $13(18,3)$ & 0 \\
Oct. 1986 & 203 & $23(11,3)$ & $6(2,9)$ & 1 \\
Nov. 1986 & 227 & $17(7,5)$ & $4(1,7)$ & 0 \\
Des. 1986 & 272 & $18(6,6)$ & $4(1,5)$ & 0 \\
\hline Total & 773 & $67(8,6)$ & $27(3,5)$ & 1 \\
\hline
\end{tabular}

Walaupun penilaian efektivitas dari vaksin ini baru dapat ditetapkan setelah analisa data dari 2 tahun follow up, penderita demam tifoid di daerah vaksinasi, setelah vaksinasi, namun data tabel diatas telah memperlihatkan adanya penurunan S. typhi yang berarti pada 4 bulan setelah vaksinasi. Hal ini merupakan suatu petunjuk adanya daya perlindungan dari vaksin ini di daerah dengan insidensi S. typhi yang cukup tinggi. Dalam tabel juga tampak adanya penurunan jumlah kasus demam tifoid oleh Salmonella paratyphi $A$. Hal ini menunjukkan adanya proteksi silang dari vaksin Ty21a oral terhadap S. paratyphi $A^{22}$

Rekomendasi vaksin Ty21a oral bisa diberikan dalam bentuk kapsul lengkap yang diminum sesuai dosis. Vaksin bisa disimpan dalam suhu dingin $2{ }^{\circ} \mathrm{C}$ $8^{0} \mathrm{C}^{24}$ Efikasi vaksin Ty21 oral juga diuji cobakan di wilayah Norte dan Occidente, Chili. Uji coba di wilayah Norte melibatkan 91.954 orang tua dan 137.697 anak sekolah usia 5-19 tahun. ${ }^{25}$ Secara acak, mereka menerima vaksin 2 dosis dalam bentuk kapsul enterik berlapis yang berisi $2-5 \times 10^{9}$ bakteri S.typhi dengan rentang pemberian 1 minggu tiap dosis, 1 dosis ty21a dan 1 dosis plasebo, atau 2 dosis plasebo. Sedangkan di wilayah Occidente melibatkan sejumlah 135.482 orang tua (96\%) dan 141.127 anak sekolah usia 6-19 tahun. $^{23,25}$ Secara acak, mereka menerima vaksin 3 dosis melalui salah satu dari 2 formulasi yang berbeda 
atau plasebo, dan diberikan dengan interval pendek (setiap hari) atau interval panjang (21 hari) antara dosis. Salah satu formulasi Ty21a adalah kapsul berlapis enterik dan yang lainnya berupa kapsul gelatin dengan 1 vaksin lyophilized dan 2 sisanya mengandung natrium bikarbonat.

Tabel 4. Efektivitas vaksin Ty21a dalam mencegah demam tifoid dan paratifoid B secara acak pada uji coba anak usia sekolah di area Norte dan Occidente, Santiago, Chili.

\begin{tabular}{|c|c|c|c|c|c|c|}
\hline Why dow & Wh & 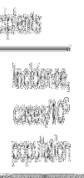 & 6ow & 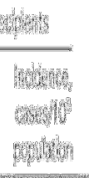 & 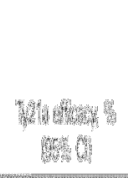 & $\beta^{*}$ \\
\hline \multicolumn{7}{|c|}{ 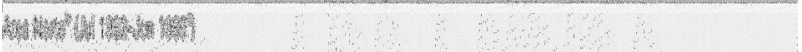 } \\
\hline Iny & 雾 & 28: & 14 & 89 & 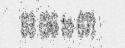 & thet \\
\hline protis & 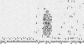 & hy & 18 & 19. & 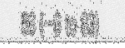 & H: \\
\hline \multicolumn{7}{|c|}{ 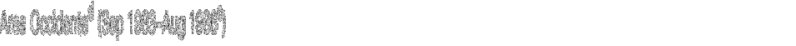 } \\
\hline 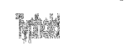 & 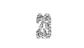 & 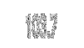 & 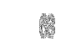 & 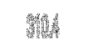 & 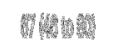 & औ䚧 \\
\hline Paratychad $B$ & 10 & 45.1 & 17 & 77.6 & $42+34076$ & 18 \\
\hline \multicolumn{7}{|l|}{ Conbined dat? } \\
\hline Twhoid & 79 & 1587 & 187 & 3800 & 584450688 & $<0001$ \\
\hline Pratyotois is & 18 & 36.2 & 35 & 71.1 & 49810731 & 019 \\
\hline
\end{tabular}

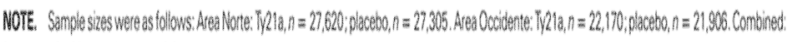

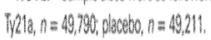

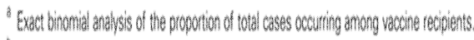

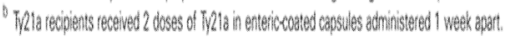

SThitysixmonth petiod of tollowe a atter vaccination.

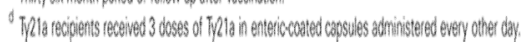

Dari data tabel diatas juga diperoleh hasil bahwa vaksin ty21a bisa memberikan perlindungan silang terhadap Paratyphoid B. Pemberian vaksin oral dalam bentuk cair lebih unggul daripada kapsul enterik berlapis. Dengan efektivitas 76,9\% : 33,2\%. Vaksin dalam bentuk cair lebih unggul memberi perlindungan terhadap anak yang lebih muda (5-9 tahun) efikasinya $82,3 \%$ dan anak yang lebih tua efikasinya $69,3 \%$. Sedangkan vaksin dalam bentuk kapsul lebih unggul melindungi anak yang lebih tua. ${ }^{26}$

Vaksin oral Ty21a telah terbukti memberi perlindungan terhadap demam tifoid. Respon imun yang timbul melibatkan Antibody Secreting Cells (ACS) perifer yang mencerminkan respon imun mukosa. Vaksin Ty21a yang diberikan melalui rute oral menimbulkan respon imun khusus spesifik dan profil immunoglobulin (dominasi IgA) terhadap Salmonella typhi. Disisi lain, vaksin Ty21a oral mempengaruhi spesifisitas antigen dari respon ACS yang berbeda dari antigen oleh sistem imun lokal dan sistemik. ${ }^{27}$

Dalam praktek klinik, demam enterik yang terjadi pada wisatawan terjadi secara global. $80 \%$ disebabkan oleh Salmonella enterica serovar typhi (S.Typhi) dan 20\% disebabkan oleh enterica serovar
Paratyphi $A$ dan $B$ (S.paratyphi $A$ dan $B) .{ }^{28}$ Vaksin tifoid parenteral inaktif, pada awalnya terdiri dari 3 jenis bakteri yaitu S.typhi, S. paratyphi A dan S.paratyphi B. $^{29}$ Namun, selama tahun 1989-2004, S.typhi mengalami resistensi terhadap antibiotik seperti kloramfenikol, amoksilin, dan trimetropin/sulfametoksasol yang tersebar di Asia Selatan dan Tenggara. ${ }^{30}$

Keefektifitasan Ty21a oral dalam pencegahan demam tifoid juga didasarkan pada percobaan yang sudah dilakukan di wilayah Norte dan Occidente. Efektivitas dinilai dan dibatasi pada bentuk vaksin yang digunakan serta pemberian regimen vaksinasi. Dalam percobaan, diperoleh hasil bahwa bentuk vaksin Ty21a bentuk kapsul enterik berlapis memberikan perlindungan yang lebih baik terhadap demam tifoid di wilayah Occidente. Dari segi pemberian regimen vaksinasi, diperoleh bahwa pemberian 3 dosis dengan interval pemberian satu hari setiap dosis memberikan perlindungan yang lebih baik. Pemberian formulasi vaksin Ty21a kapsul enterik berlapis menjadi dasar pemberian vaksin diseluruh negara berdasarkan 3 tahun pertama surveilans di Occidente. Dari 2 hasil percobaan mengenai efektivitas vaksin ty21a oral dalam hal bentuk dan pemberian regimen vaksinasinya, maka selanjutnya hal itu pula yang mendasari penggunaan vaksin Ty21a oral secara global hingga saat ini. Efikasi bentuk vaksin dan interval pemberian dosis terbaik untuk mencapai potensi vaksin sangat berpengaruh. $^{31}$

Demam enterik tifoid maupun paratifoid secara klinis banyak ditemukan. ${ }^{32}$ Saat ini, vaksin yang direkomendasikan untuk pencegahan demam tifoid bagi para wisatawan adalah vaksin polisakarida $\mathrm{Vi}$ parenteral dan Ty21a oral. ${ }^{31}$ Vaksin polisakarida Vi memberikan perlindungan dengan cara menimbulkan antibodi terhadap antigen Vi. Namun, oleh karena antigen Vi tidak terdapat pada S.paratyphi $A$ dan $B$, vaksin polisakarida $\mathrm{Vi}$ tidak dapat memberikan perlindungan silang terhadap demam enterik yang disebabkan serotype S.paratyphi $A$ maupun S.paratyphi B.

Sebaliknya, vaksin Ty21a oral yang berasal dari S.typhi hidup yang dilemahkan, tidak memiliki antigen Vi sehingga mampu memberikan perlindungan dengan cara menimbulkan antibodi serum dan mukosa terhadap antigen $\mathrm{O}$ dan $\mathrm{H}$, serta antigen lain melalui stimulasi respon imun yang diperantarai sel atau Cell-Mediated Immune (CMI) yang melibatkan sel T sitotoksik. ${ }^{25}$

Sebelumnya diperoleh data percobaan dari area Norte dan Occidente dimana efikasi vaksin Ty21a oral memberikan perlindungan sedang terhadap serotipe paratifoid B. Dari hasil percobaan di area Norte dan Occidente masih sedikit kasus penyakit 
S.paratyphi A yang ditemukan. Sehingga hal ini belum memberikan kemungkinan yang cukup mengenai Ty21a yang juga bisa memberikan daya perlindungan terhadap S.paratyphi $A^{33}$

Secara imunologi, bisa dijelaskan proses perlindungan silang vaksin Ty21a terhadap serotipe paratifoid. Salah satunya didasarkan pada epitop antigen $O$. Selain itu, pemberian 3 dosis vaksin ty $21 a$ oral dalam bentuk kapsul enterik berlapis (dengan interval 2 hari dalam pemberian tiap dosis) menstimulasi pembentukan Antibody-Dependent Cellular Cytotoxicity melalui spesifisitas antibodi IgA terhadap sel mononuklear yang berperan untuk membunuh bakteri Salmonella. ${ }^{34}$ Pemberian post imunisasi vaksin ty21 oral 3 dosis juga memperlihatkan efek aktivitas sel mononuklear dalam membunuh S.paratyphi $A$ dan S.paratyphi $B$. Sebaliknya, efek antibakteri terhadap S.paratyphi $C$ tidak memberikan perlindungan disebabkan tidak adanya epitop bersama antigen $\mathrm{O}$ antara S.typhi dan S.paratyphi C.

Ty21a juga menstimulasi respon imunologi klasik yang kuat melalui respon imun yang diperantarai sel termasuk fungsi sel T spesifik hingga pada beberapa mekanisme efektor dalam memproduksi IFN- $\quad \gamma$ dan sitokin-sitokin ketika distimulasi oleh basil utuh inaktif dan flagel dari S.typhi sehingga pada hasil akhirnya sel T sitotoksik bisa membunuh sel target yang terinfeksi oleh S.typhi. ${ }^{25}$

\section{Pembahasan}

Vaksin Ty21a sangat berpotensi untuk mencegah transmisi demam tifoid bagi manusia terlebih wisatawan yang berisiko terpapar di daerah yang memiliki insidensi tinggi terhadap demam tifoid. Vaksin ini dapat memberikan perlindungan jangka panjang bukan saja dari S. typhi tapi juga dri S. paratyphi A dan B. Perlindungan kekebalan aktif melalui Cell Mediated Immune, Antigen Secreting Cells dan memberikan respon imun khusus spesifik dan profil imunoglobulin A (IgA) yang lebih kuat daripada vaksin parenteral. Potensi vaksin juga dipengaruhi oleh pemberian dosis vaksinasi dimana diperoleh hasil pemberian 3 dosis vaksinasi selang sehari tiap dosis, memberikan efektivitas mencapai $50-80 \%$ dan efektivitas selama 3 tahun. Bentuk vaksin tidak terlalu mempengaruhi efektivitas vaksin secara signifikan, sebab bentuk vaksin dalam efektivitasnya juga dipengaruhi oleh usia dimana dari hasil percobaan sebelumnya, vaksin dalam bentuk cair lebih unggul memberi perlindungan terhadap anak yang lebih muda (5-9 tahun) efektivitasnya 82,3\%, sedangkan vaksin dalam bentuk kapsul lebih unggul melindungi anak yang lebih tua.

\section{Simpulan}

Vaksin Ty21a oral terbukti efektif dalam pencegahan demam tifoid. Karena, selain memiliki efektivitas yang tinggi, vaksin ini juga memiliki lebih sedikit efek samping jika dibandingkan dengan vaksin tifoid parenteral. Vaksin Ty21a oral bisa memberikan proteksi jangka panjang melalui respon imun Immunoglobulin A yang lebih kuat pada saluran cerna dibandingkan dengan vaksin parenteral. Oleh sebab itu, vaksin ini direkomendasikan bagi para wisatawan yang hendak berkunjung ke daerah endemis.

\section{Daftar Pustaka}

1. Handszuh H. Tourism trends and patterns.

European Conference on Travel Medicine. Venice, Cini Foundation, 25-27 March 1998. www.ectm5.org/1998.pdf

2. Travel Medicine: Helping Patients Prepare for Trips Abroad. http://www.aafp.org/afp/980800ap/dick.html

3. Zuckerman JN. Recent developments:Travel medicine.BMJ 2002;325: 260-4

4. Zuckerman, Jane N, Jong, Elaine C. Traveler's Vaccines. Ed-2. USA: PMPH; 2010: 163-75.

5. Germanier R and Furer E. Isolation and Characterization of Gal E mutant Ty 21 a of Salmonella typhi: A candidate strain for a live, oral typhoid vaccine. J Inf Dis 1975; 131: 553-8.

6. Gilman RH, Hornick RB, Woodward WE, Du Pont $H L$, Snyder MJ, Levine MM and Libonati JP. Immunity in typhoid fever evaluation of Ty 21 a, an epimeraseless mutant of $S$. typhi as a live oral vaccine. J Inf Dis 1977; 136: 717-23

7. Hejfec LB, Salmin LV, Lejtman MZ, Kuzminova ML, Vasileva AV Levina LA, Bencianova TG, Pavloba EA and Antonova AA.A controlled field trial and laboratory study of live -typhoid vaccine in the USSR. Bull WHO 1966; 34: 321-9.

8. Yugoslav Typhoid commission. A controlled field trial of the effectiveness of aceton-dried and inactivated and heat-phenolinactivated typhoid vaccines in Jugoslavia. Bull WHO 1964; 30: 62330.

9. Tapa S and Cvjetanovic B. Controlled field trial on the effectiveness of one and two doses of acetoneinactivated and dried typhoid vaccine. Bull WHO 1972; 52: 75-80.

10. Wandan $\mathrm{MH}$, Serie $\mathrm{C}$, Cerisier $\mathrm{Y}$, Sailam $\mathrm{S}$ and Germanier R A controlled field trial of live Salmonella typhi strain Ty 21 a oral vaccine against Typhoid; Three year results. J Inf Dis 1982; 145: 292-5.

11. Levine MM, Black RE, Ferrecio C, Clements ML, Lanata C, Rooney J and Germanier R. The efficacy of attenuated Salmonella typhi oral vaccine strain Ty 21 a evaluated in controlled field trials 
Development of Vaccines and Drugs against Diarrhea 11th Nobel conference, Stockholm 1985 pages: 90-101. Eds Jan Holmgren Alf Lindberg Roland Millby.

12. Chuttani CS, Prakash K, Vergese A, Sharma U, Shingha $P$, Ghosh Ray B dan Agarwal A. Controlled field trial of oral killed typhoidvaccine in India. Inf J Epidemiol 1972.

13. Stubi $\mathrm{CL}$, Landry PR, Petignat $\mathrm{C}$, et al. Compliance to live oral Ty21a typhoid vaccine and its effect on viability. J Travel Med 2000; 7: 133-37.

14. Cryz SJ. Patient compliance in the use of Vivotif Berna ${ }^{\circledR}$ vaccine, typhoid vaccine, live oral Ty21a. J Travel Med 1998; 5: 14-17.

15. Parry CM. Epidemiological and clinical aspects of human typhoid fever. In: Pietro mastroeni, ed. Salmonella infection: clinincal, immunological and molecular aspects. UK and new York: Cambridge University Press; 2006.

16. Alwi I, Setiati S, Setiyohadi B, Simadibrata M, Sudoyo AW, editor. Buku Ajar Penyakit Dalam. Ed4. Jakarta: Pusat Penerbitan Departemen IImu Penyakit Dalam FK UI; 2006: 1775.

17. Budiyono $\mathrm{M}$, Soewandoyo $\mathrm{E}$ dan Juwono R. Typhus abdominalis dengan Penyakit Perdarahan Usus yang Massif. Maj. Kedokteran Indonesia 1986; 36 (4): $179-83$.

18. Iskandar Z. Typhus abdominalis di R.S. Persahabatan, Jakarta. Naskah Lengkap Kopandi HI, Bandung, 1975.

19. WHO. Background document: The diagnosis, treatment and prevention of typhoid fever. Switzerland: WHO Publication; 2003.

20. WHO. Drug resistant salmonella. (Online). April 2005 (cited 27/02/07);(2 pages). Available from: URL:

http://www.who.int/mediacenter/factsheets/ fs139/en/ print.html

21. http://kesehatan.kompasiana.com/medis/2011/03 L27/vaksinasi-tifoid-pada-infeksi-salmonella/

22. Cyrus H.Simanjuntak, Fred P. Paleologo, Narain H.Punjabi. Uji Coba Vaksin Oral Ty 21 A Salmonella Typhi di Kompleks Pertamina. Pusat Penelitian Penyakit Menular, Badan Litbangkes Depkes RI, Jakarta. 1986.

pages: 90-101. Eds Jan Holmgren Alf Lindberg Roland Millby.

23. Levine $M M$, Black RE, Ferrecio C, Clements $M L$, Lanata C, Rooney J and Germanier R. The efficacy of attenuated Salmonella typhi oral vaccine strain Ty 21 a evaluated in controlled field trials Development of Vaccines and Drugs against Diarrhea 11th Nobel conference, Stockholm 1985 pages: 90-101. Eds Jan Holmgren Alf Lindberg Roland Millby.

24. Ranuh et al, 2008, Pedoman Imunisasi di Indonesia edisi ketiga, Badan Penerbit Ikatan Dokter Anak Indonesia, Jakarta
25. Black RE, Levine MM, Ferreccio $C$, et al. Efficacy of one or two doses of Ty21a Salmonella typhi vaccine in enteric-coated capsules in a controlled field trial. Chilean Typhoid Committee Vaccine;1990(4):8-81.

26. Levine MM, Ferrecio C, Ornitz RN, Lanata C. Comparison of enteric-coated capsules and liquid formulation of Ty21a typhoid vaccine in randomised controlled field trial. 2003.

27. Microbial Pathogenesis, Volume 10, Issue 2, February 1991, Pages 117-126. A. Kantele, H. Arvilommi, J.M. Kantele, L. Rintala, P.H. Mäkelä.

28. Crump JA, Luby SP, Mintz ED. The global burden of typhoid fever. Bull World Health Organ 2004;82:346-53.

29. Levine MM Typhoid fever vaccines. In: Plotkin SA, Orenstein WA, editors.Vaccines. 3. Philadelphia: W.B. Saunders; 1999. p. 781-814.

30. Rowe B, Ward LR, Threlfall EJ. Multidrugresistant Salmonella typhi: a worldwide epidemic. Clin Infect Dis 1997;24(Suppl 1):106-9.

31. Salerno-Goncalves R, Pasetti MF, Sztein MB. Characterization of $\mathrm{CD}^{+}$effector $\mathrm{T}$ cell responses in volunteers immunized with Salmonella entericaserovar Typhi strain Ty21a typhoid vaccine. J Immunol2002;169:2196-203.

32. Wahdan $M H$, Serie $C$, Cerisier $Y$, Sallam $S$, Germani er R. A controlled field trial of live Salmonella typhistrain Ty21a oral vaccine against typhoid: three-year results. J Infect Dis 1982;145:292-6.

33. Woodward TE, Woodward WE. A new oral vaccine against typhoid fever. J Infect Dis 1982;145:289-91.

34. Hornick RB, DuPont HL, Levine MM,et al. Efficacy of a live oral typhoid vaccine in human volunteers. Dev Biol Stand 1976;33:89-92. 